\title{
Management Styles of Polish Managers
}

\author{
Dr Ireneusz Żuchowski*
}

\begin{abstract}
:
Management style is distinctive and relatively stable behaviour of the manager affecting the employees of the subordinate group. Management style involves personal interactions as well as in a large extent a manager spontaneous reaction in a direct contact with the subordinates.

The theoretical part of this work has aimed at presenting problems of management styles and discussed the factors influencing the choice of management style. Furthermore, it provides the leader with the selected concepts and management styles. Particular attention was paid to the Blake Mounton Managerial Grid and W.J. Redline Concepts. The research part presents of the author's own research and the results obtained by graduates preparing their works under the direction of the author, which are based on the Blake Mounton Managerial Grid. The surveys were conducted among managers of All types of companies (small, medium, large) and different types of public institutions (Police, City Council, Fire Station).

These results were contrasted with the results of the management styles presented in the works of other Polish authors. The analysis of the own results and other writers indicates that the most identified style is democratic style. While the studies of other authors show the frequent use of this style but also pay attention to using participation and firefighter management styles.
\end{abstract}

Key Words: Polish managers, Management style, Blake Mounton Managerial Grid.

*High Economic - Social School in Ostroleka, Faculty of Business Management, Poland izuchowski@wses.edu.pl 


\section{Introduction}

Management style is the way of affecting the employees of the subordinate group, consolidated in its behaviour, having the influence on the group and its results (Havlíček, Thalassinos and Berezkinova, 2013). To put it simple, it is the way of stimulation or management (Pomykało, 1995). The choice of style depends on where we see the chance for the particular company, the fundamentals of the economy and other economic issues (Mroziewski, 2010; Thalassinos et al., 2012 and 2014). It is found in, characteristic for a particular person, methods and techniques which make the subordinate group work better and more efficently. The style mentioned above is characterised by many factors, such as people's nature or temper, penchants, aptitude or even health (Kobyliński, 2005; Břečková, Havlíček, 2013). Tradition and cultural patterns as well as working conditions and the current organizational situation can also influence the choice of the appropriate style the manager uses to lead the people.

Problems with management styles appeared clearly in many empirical researches when the trait theory was proven amiss, making it impossible to discover the mental structure characterising an effective manager (Mroziewski, 2005).

\section{Literature}

The first researches on management styles began in 1930s. The research was started by American psychologists, R. Lippitt and R.K. White who had been inspired by K. Lewin the German immigrant psychologist living in the USA (Pomykało, 1995). The outcome of their effort is the model of three styles, namely, autocratic, democratic and laissez faire.

Autocratic management style - the manager wielding this style is the person who gives orders and instructions, demands to be listened to, and if there is no compliance, he draws apposite conclusions. The etymology of the word suggests its meaning. It comes from Greek: autos meaning self and kratos meaning power; autocracy, government in which one person has unrestricted powers and control over others. An autocratic rule mainly by punishing his subordinates, however, he does not refrain from praise, whose form is of his own choice. The research shows that the autocratically led groups achieve high productivity, however, the quality of work, and especially the originality and the method of the production is average.

Democratic management style - this style is characterised by the fact that the manager creates his subordinates conditions in which they can show initiative and independence and they are invited to participate in decision-making. Democracy, from Greek demos meaning people and kratos meaning power; it literary means the power of the people. This form of government allows people to participate in governing the country. In order to get approval for his actions and convince the people about the justness of his decisions, he organises the meetings and 
conferences. Interaction with people is dominated by directness and freedom, and the decisions that are taken are the result of the consensus (Kobylinski, 2005). The research results over the management style that are close to this one show that the efficiency of work is lower than in an autocratically led group. However, the quality of work is higher, and the products as well as the production display a lot of originality. The level of work motivation is also high. The members of the group perceive this management style as positive and the relationships within the group are friendly. What is more, they share opinions about their work eagerly. During discussions about the group, they are the part of, more than members of the autocratically led groups, they use pronouns we instead of I (Pomykało, 1995). According to psychologists, the group is united if its members equate with the whole group.

Laissez Faire management style - also referred to as non-interfering or passive, comes from French, meaning let do or let it be done (Kobyliński, 2005). The manager using this style is in fact unable to administer, control or coordinate any tasks. He is directed by the course of events or directives coming from the top and the bottom (Kobyliński, 2005). The effectiveness and quality of work are lower than in the groups where the manager's behaviour is similar to the autocratic or democratic style (Pomykało, 1995; Havlíček and Schlossberger, 2013).

In their research, R. Lippitt and R. K. White proved that people and groups, which they constitute, can only be managed effectively in an autocratic or a democratic way. The reason for this is that, laissez-faire style denies the management style giving all the power in decision-making to the members of the group. Later it was shown that the effectiveness of each style depends on the circumstances in which the subordinate group is.

Management styles are classified in many ways by different authors. For instance, J. A. C. Brown divides managers according to the following criteria. Autocratic manager, a person who gives orders, and imposes tasks without consultation with the subordinates. He expects that his directives will be completed without any objection. He praises and punishes his subordinates personally and maintains distance from the workers. Autocratic managers can be divided into: Strict autocrats who are mainly domineering, but righteous; follow strict procedures, do not delegate their eligibilities and try to self-control as much as possible; benevolent autocrats, who feel thoroughly responsible for their subordinates and try to create the best possible working conditions, but they decide what is best for the worker on their own, and they expect the worker to accept that; clumsy autocrats who are characterised by despotism and unpredictability towards their employees, and the way they treat them depends on the mood they are in, democratic manager, knows his place in the hierarchy of the organisation and he is aware of his coordinator role at the workplace. What is more, he runs the company by delegating his eligibilities in order to ensure the efficient functioning of the company lest he is absent, manager following laissez-faire pattern, in fact such a person is unable to act as a manager 
and to do any of the managerial duties (scheduling, coordination and control of the employees' tasks)

Management styles, suggested by J. A. C. Brown, are strictly connected with the features of character of the person at the managerial position. The leader style which the manager represents plays the main role in each of these patterns, and it forejudges the management style (Pomykało, 1995).

Another concept was proposed by professor D. McGregor who distinguished two contrasting management styles:

Theory $\mathrm{X}$, is the management style concentrated on the human nature. Highly restrictive supervision, direct management and punitive atmosphere are the result of the conviction that workers are inherently lazy, avoid responsibility, and show little ambition (Kieżun, 1998). In this theory, the manager's role must rely on constant coercion of the subordinates by means of different sanctions, because it is taken for granted that employees show little professional and family life ambition.

Theory Y, is based on different motivational aims, namely, it assumes that work is as natural a need as relaxation and entertainment. Man prefers self-control and selfmotivation and he does not avoid responsibility but he is eager to search for it if the conditions allow (Kieżun, 1998).

According to D. McGregor, the style the manager will implement depends on the conviction about the workers' qualifications and attitude to work. Theory $\mathrm{X}$ assumptions are symmetrically different from Theory Y. So both theories are a form of assumption, and how the workers behave in reality is closer to the former or the latter theory, which allows to choose one of them.

One of the most interesting classifications of management styles referring to a manager's personality, which is included in reference books, is the one presented by G. S. Sargie. He writes about five typical styles: 1. personal style - introvertive - the manager is egocentric, and his management is autocratic. He makes all the decisions by himself believing that he is infallible. Delegating duties is unacceptable. This type of manager is demanding and expects discipline from his subordinates and at the same time he emphasises supervision. According to the employees he commits himself emotionally and he tends to be moody. He is also entrepreneurial and full of energy to work. Another personal style - impulsive - the manager is not only enthusiastic but also impulsive and he reacts impulsively when dealing with people and duties. Despite an impressive creativity, this kind of manager is not consequent in completing his aims and what is more he brings chaos to the company. The third style is impersonal - above all, the manager is restrained and reserved. He acts rationally and does not engage emotionally into company matters. He delegates tasks precisely taking into account the employees qualifications. The manager is disencumbered from decision-making due to a sufficient level of decentralisation and a settled decision-making process considering the advisers' clues. The fourth 
style - collective - the manager represents the democratic form of leadership. He treats his subordinates benevolently. He does not only see himself as a supervisor but also, and above all, the member of the team. Operational decisions are made as a result of discussion. The fifth style - peaceful - the manager is exceptionally calm. When dealing with employees, the manager stays calm and peaceful. He makes sensible decisions with restricted collegial help.

\section{Managerial Grid by R.R. Blake and J.S.Mouton}

One of the best known leadership style concepts is the managerial grid. Not only does it include the description of the potential behaviour of the leaders, but also the suggestions concerning the ideal management style, which means a simultaneous concern for people and concern for production, assuming that both these concerns do not collie (Pocztowski, 2003). Two American authors Robert R. Blake and Jane S. Mounton developed a framework which was a collection of different management styles which depend on the manager's degree of concentration on the tasks or employees matters, assuming that tasks and people are two opposed elements (Penc, 2000). Blake Mouton Managerial Grid is based on two behavioural dimensions. The horizontal axis depicts the manager's concern for tasks, and the vertical axis refers to the concern for people and the relations among them. The leader's intention on the certain orientation is defined by standard nine (Pocztowski, 2003). Managerial Grid defines the scale of managerial behaviour based on different ways of combining styles: concern for tasks and people, where each is presented on a scale form 1 to 8 (Tokarski, 1997).

Blake and Mouton's classification of the individual management styles has become incredibly popular. The Managerial Grid that was created by Blake and Mouton presents 81 leadership styles, but the authors restricted it to 5 basic ones, which are placed in the four corners of the grid with the fifth one in the middle, namely:

The Impoverished Style $<1.1>$, similar to 'laissez faire', the manager representing this style is a very weak leader and is referred to as 'a dummy', because this kind of the manager shows low concern for both people and tasks, he avoids getting into contact with subordinates as well as refrains from making decisions. Managers use this style to preserve their job and position,

Country Club Style <1.9>, the manager has low concern for tasks, but high concern for people, which means that he satisfies all sorts of employees' needs, trying to create the best atmosphere possible, which in a result makes a false impression that all the employees are members of a 'big happy company-family', Dictatorial Style $\langle 9.1\rangle$, the main objective for the manager is the realisation of the tasks, and because of that the concern for people is restricted to the minimum. All the personal problems are solved with the concern for the company, and the manager appoints the tasks for the employees on his own, without taking into account their opinions, and what is more, he does not allow his employees to participate in decision-making, 
The Team Style <9.9>, the manager pays high concern for people as well as tasks, and the company business is treated equally with the employees' personal matters, which places the working atmosphere together with the level of the realisation of the tasks at the high level. This is the ideal style, which should be every manager's pursuit, however, it is almost impossible to achieve it fully, because in reality the manager always turns, more or less, to one side of the managerial grid. This style is characteristic of the modern managers,

The Middle-of-the-Road Style <5.5>, the concern for tasks as well as people is at a medium level, however, it keeps a satisfactory level of company performance. It also allows avoiding conflicts among the fellow workers. This style is the most effective in bureaucracy-oriented companies.

Picture 1. Blake Mouton Managerial Grid

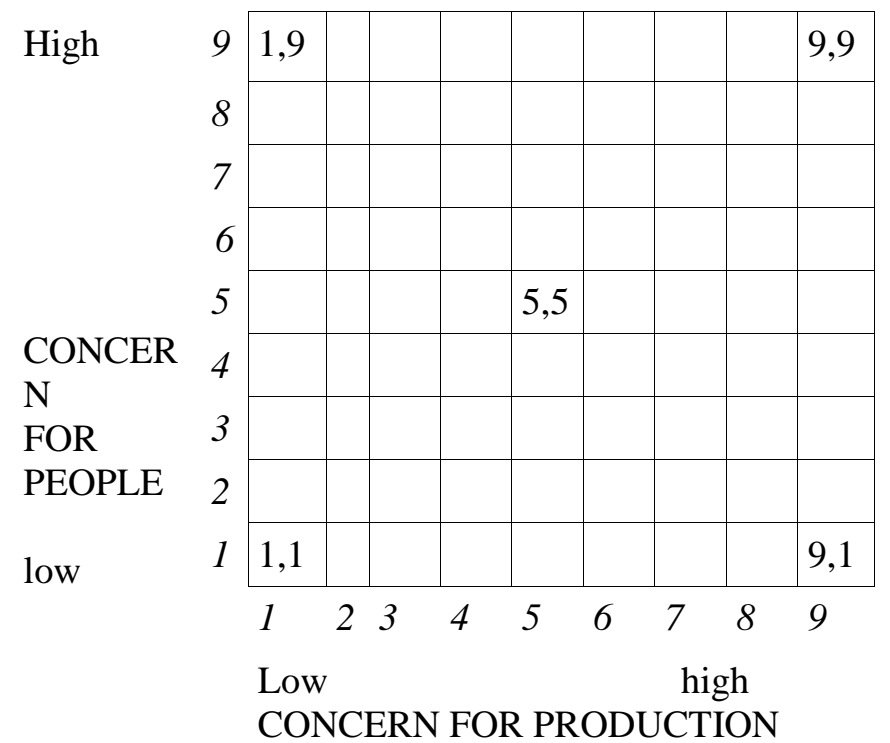

Source: Kurnal J., 1976, 'Nowe spojrzenie na proces podejmowania decyzji kierowniczych '[New Approach to the Process of Managerial Decision-Making], ,Przeglad Organizacyjny”, $n r$ 4-5.

According to the authors of the managerial grid, the manager's work is the most effective when he shows concern for people as well as tasks, and when people feel that they are the part of the company, which is a highly-integrated and powerful group. What is more, people are aware that they do not mean much without their superior and they can do little for the company (Penc, 2000, Kaczmarek, Sikorski, 2011).

Style grid according to W. J. Reddin, P. Hersey and K. H. Blanchard 
44

In works of American theorist W.J. Reddin we can find the development of R. R. Blake and J. S. Monton concepts, however, he added the third dimension, which is concern for manager's effectiveness, to the two factors (dimensions) that had been proposed. W.J. Reddin creates a concept which can be called the 3D Theory (Gołębiewska, 2000). Based on the 3D Theory it can be noticed that the author distinguishes three main management style groups:

basic styles, less effective styles, more effective styles.

Picture 2. The characteristics of eight management styles by J.W. Reddin

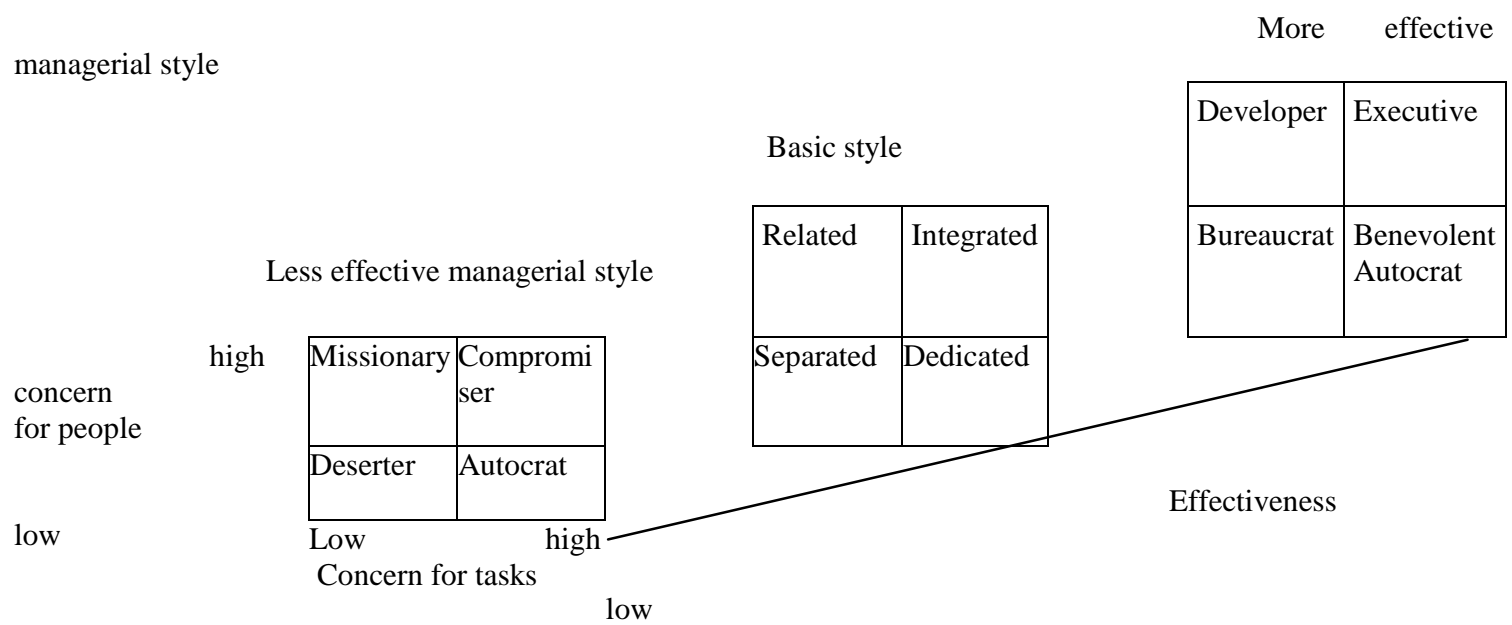

Source: March J. G., Simon H. A., 1964, 'Teoria organizacji'” [Organisations], Wyd. 1, Warszawa: Polskie Wydawnictwo Ekonomiczne, p. 82.

As a result, when analysisng management style grid we can distinguish twelve basic styles, although W.J. Reddin distincted only eight, dividing them into more and less effective (Table 1.)

Table 1. Management styles according to J.W. Reddin

\begin{tabular}{|c|c|c|}
\hline Basic types & $\begin{array}{l}\text { Characteristics of } \\
\text { less effective styles }\end{array}$ & $\begin{array}{l}\text { Characteristics of } \\
\text { more effective styles }\end{array}$ \\
\hline Separated & $\begin{array}{l}\text { 1. Deserter - an escape from } \\
\text { management. This type of manager } \\
\text { does not solve the problems that he } \\
\text { is supposed to, or he passes them on } \\
\text { other people. He is perceived to be } \\
\text { uncommitted to work. }\end{array}$ & $\begin{array}{l}\text { 2. Bureucratic - pays much } \\
\text { attention to formal procedures } \\
\text { and to control over the } \\
\text { subordinates. He is perceived to } \\
\text { be conscientious and meticulous. } \\
\text { High scores tend to be } \\
\text { systematic. }\end{array}$ \\
\hline Dedicated & $\begin{array}{l}\text { 3. Autocratic }- \text { tends to reach his } \\
\text { aims at all costs. He is perceived as } \\
\text { reserved, domineering and }\end{array}$ & $\begin{array}{l}\text { 4. Benevolent Autocratic - he } \\
\text { tries to realize his tasks without }\end{array}$ \\
\hline
\end{tabular}




\begin{tabular}{|c|c|c|}
\hline Integrated & $\begin{array}{l}\text { unfriendly. All these make that he is } \\
\text { unable to get good results, not to } \\
\text { mention a good atmosphere in the } \\
\text { team. } \\
\text { 5. Missionary - puts a lot of effort } \\
\text { in making best possibile } \\
\text { interpersonal relationships. He is } \\
\text { perceived as a kind, but an } \\
\text { ineffectual man who cannot assign } \\
\text { and execute tasks. } \\
\text { 7. Compromiser - very prone to the } \\
\text { external influence. He resorts to } \\
\text { compromise easily. He focuses on } \\
\text { solving current tasks, neglecting } \\
\text { those far-reaching. }\end{array}$ & $\begin{array}{l}\text { disaffecting others. He treats } \\
\text { people instrumentalny, but he } \\
\text { trusts them to some extent and } \\
\text { leaves people to their work. } \\
\text { Thanks to this he can get good } \\
\text { results even if he aims very } \\
\text { ambitiously. } \\
\text { 6. Developer - he is believed to } \\
\text { be trusty, willing to delegate } \\
\text { tasks to his subordinates, and } \\
\text { what is more, he cares for his } \\
\text { workers' development. This } \\
\text { attitude guarantees success, } \\
\text { which becomes higher together } \\
\text { with a better team integration. } \\
\text { 8. Executive - he can set himself } \\
\text { and his subordinates high golas. } \\
\text { He emphasises team work. He } \\
\text { can choose accurate methods of } \\
\text { work, which affirm the efficiency } \\
\text { in task realization. }\end{array}$ \\
\hline
\end{tabular}

Source: G. Gołębiowska, 2000, 'Kierowanie zespołami pracowniczymi'” [Managing the Teams of Managers] [w:] Podstawy organizacji i zarzadzania, Wydawnictwo Naukowe Uniwersytetu Szczecińskiego, Szczecin. p.253.

\section{Research}

Thirty workers took part in the research that was conducted in the Polish factory of the international production company in 2010. The main areas of production are purchase, grading and freezing of friut and vegetables. These raw materials are supplied by farmers. The compnay also produces fruit pulp. The company has implemented quality management systems, such as GMP, GHP, HACCP, ISO 22000: 2005. The main objective of the research was the identification of the management style and the managers' assessment in employees' opinion. The research was based on an author's questionnaire. The resulsts indicated that the managers have adapted the Country Club Style. The managers and the management styles were evaluated positively by the employees (Pardo, 2010).

In 2010 one of the author's graduands (Dąbrowski, 2010) conducted a research in two Post Offices in Ostrołęka that are the part of Poczta Polska S.A. There are eight post offices in the town and one of them is the branch. These post offices are subordinate to Regional Branch of the Postal Service in Ostroleka. Post Offices no. 1 and no. 2 are the biggest in the town. The research was conducted by means of the questionnaire based on the managerial grid self-assessment test. The questionnaire 
was directed at the empolyees subordinate to the assessed managers in order to identify the management style. Thirty employees subordinate to Post Office no. 1 manager and twenty five employees form Post Office no. 2 participated in the research. The results of the research indicated that both managers apply similar management style (Picture 3).

After the analysis of the questionnaire it can be seen that management style of both managers are marked close to each other on the mangerial grid. They are marked between Middle-of-the-Road and Team Style. This means that the postmasters have a relatively high motivation for realization of the set aims as well as satisfying their employees' needs. The differences between the styles represented by the postmasters are as follows. In Post Office no. 1 the postmaster focuses more on tasks, however, in Post Office no. 2 the postmaster prefers workers-oriented management.

Picture 3. Postmasters' leadership styles juxtaposed with five basic leadership styles by Robert R. Blake and Jane S. Mouton

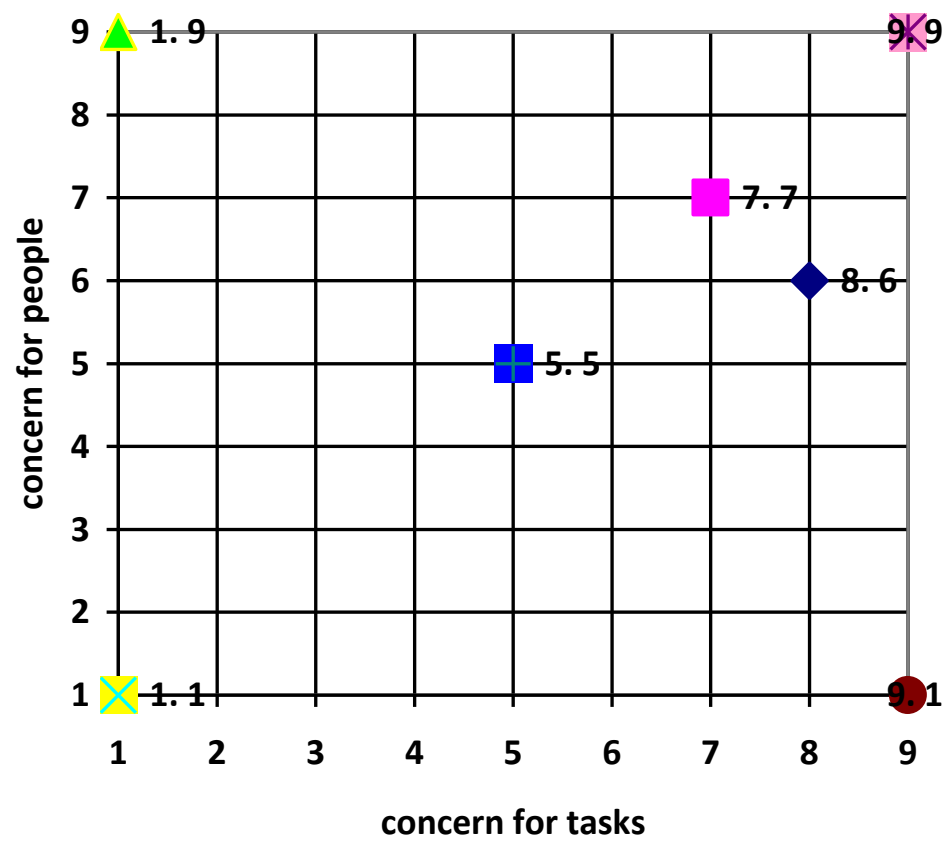

\begin{tabular}{|l|}
\hline Postmaster in Post Office no. 1 \\
Postmaster in Post Office no.2 \\
Country Club Style \\
X Impoverished Style \\
X Team Style \\
Dictatorial Style \\
Middle-of-the-Road Style \\
\hline
\end{tabular}

Source: R. Dąbrowski, 2010, 'Styl kierowania pracownikami w Urzędzie Pocztowym Nr1 oraz Urzędzie pocztowym $\mathrm{nr} 2 \mathrm{w}$ Ostrotęce" [Management style of workers in Post Office 
no.l and Post Office no. 2 in Ostrołęka], Wyższa Szkoła Ekonomiczno - Społeczna w Ostrołęce typescript.

Management style research was being conducted in Bank Spółdzielczy [Cooperative Bank] in Goworowo in 2010 (Stachurska, 2010). The bank in Goworowo is the member of Mazovian Regional Bank Ltd. which consists of 77 units. Bank Spółdzielczy [Cooperative Bank] in Goworowo is a small unit employing a little more than twenty people. Fifteen people from all the bank branches participated in the research. The analysis of the research indicated that the so called benevolent autocratic was the prevalent management style. The interviewees described their managers as people feeling responsible for their employees, trying to guarantee the finest working conditions, together with independent decision-making without consulting the subordinates.

The aim of the research conducted in the local government unit - Town Hall of Ostroleka was the identification of management style used by department managers and specification of the influence on the personnel of the department (Lendzioszek 2010). The research was conducted in 2010. Town Hall consists of twenty one departments. The research was conducted by means of the author's questionnaire which was directed to managers of the chosen departments. The results of the survey showed that $33 \%$ of the managers declare that they use democratic style in their daily work. The remaining managers pointed that the management style depends on the circumstances. The detailed analysis of the results has proven that the managers' behaviour is close to the Team style.

The research that took place in the bicycles and bicycle frames factory was conducted in 2011 (Osowska, 2010). The company is the biggest manufacturer of bicycles on the Polish and European market as well as the leading retailer on the domestic market. The aim of the research was to determine the management style used by the managers and to determine the desired manager profile. The research was conducted among twenty four employees of the company using an author's questionnaire. The majority of the interviewed (66\%) claimed that the managers use the autocratic style.

However, 21\% appraised their managers' style as democratic. From the respondents' point of view, the most appropriate would be democratic style.

In 2011 the research was conducted among three managers of Stokrotka Supermarket Ltd (Kuczyńska, 2010). Stokrotka is the memeber of Grupa Handlowa Emperia. The coordinator of the group is Emperia Holding S.A. which has been a publically traded company since 2002. Ten managers participated in the research. It was conducted by means of a self-assessment management test based on the managerial grid (Tokarski, 1997). Women aged from 18 to 45 comprised the group of the assessed managers. The managers' level of qualifications is comparable. Half of the managers hold university diplomas whereas the other half just has secondary 
education. The analysis of the test indicated that the predominant group (80\%) is the managers using the democratic style. The remaining part uses the liberal style (Picture 4).

Picture 4. Management styles used by chain stores managers.

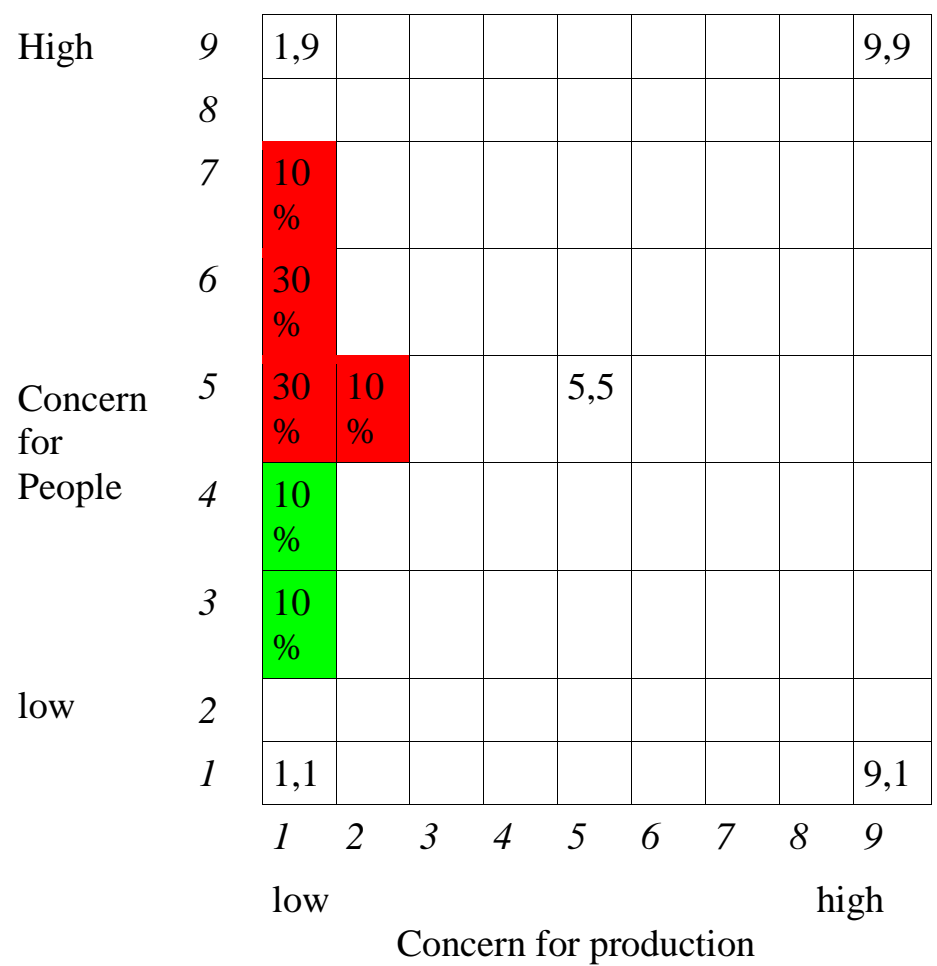

Source: K. Kuczyńska, 2010, 'Style kierowania pracownikami na przykładzie sklepów Stokrotka w Ostrotęce", [Management Styles in Stokrotka Supermarkets in Ostroleka] Wyższa Szkoła Ekonomiczno - Społeczna w Ostrołęce, typescript.

Police is a uniformed service in which the only acceptable form of management should be autocratic. In 2011 the research was undertaken among twenty five policemen from County Police Headquarters in Wyszków. The area of the research was the management style identification of the supervisor of the group mentioned. It was conducted by means of a self-assessment management test based on the managerial grid (Tokarski, 1997). The results of the research demonstrated that policemen perceive their supervisor as democratic.

Strychno and Kulczycka conducted the research on the management style in health centres. The authors of the study undertook the research in five provisional hospitals in lubelskie voivodship among 51 interviewees. The questionnaire was completed by 15 people from the management - nurses and midwives and the remaining 36 respondents were the unit midwives. The authors used the 
questionnaire with eight groups of tasks. The management had to assign 10 points to the statements describing their behaviour in the most adequate way. They could assign these 10 points without restraint among all the statements or they could choose one statement in one of the eight groups. Based on that the authors have marked off the management styles used by the hospital managers which was the main group participated in this research. The evaluation criterion was the management styles proposed by J.W Reddin and modified by the authors.

This study has shown that the most commonly used style in case of the midwives management was the executive. The autocratic was the least popular style. The midwives declared that the autocratic style was the most unlikely to be found in their supervisors' behavior (Strychno, Kulczycka, 2003) (Table 2).

Table 2. Nurse administration management styles in their own opinion juxtaposed with management styles according to midwives (average)

\begin{tabular}{|l|l|l|}
\hline \multirow{2}{*}{ Management style } & Position \\
\cline { 2 - 3 } & Nurse administration & midwife \\
\hline Executive & 17,12 & 16,12 \\
\hline Developer & 14,82 & 14,15 \\
\hline Missionary & 10,45 & 13,08 \\
\hline Bureucratic & 10,13 & 9,77 \\
\hline Benevolent autocratic & 10,93 & 8,35 \\
\hline Compromiser & 6,53 & 7,77 \\
\hline Deserter & 5,19 & 7,31 \\
\hline Autocratic & 4,77 & 3,85 \\
\hline
\end{tabular}

Source: E. Strychno, K. Kulczycka, ’Style kierowania w praktyce zarzadzania zespołami położnych" [Nurse administration management styles in practice], ANNALES UNIVERSITATIS MARIAE CURIE-SKŁODOWSKA LUBLIN - POLONIA, VOL.LVIII, SUPPL. XIII, 24, SECTIO D, 2003, p. 204-208.

The same results were presented by E. Strychno, L.Wdowiak, W. Kruk in a dissertation entitled Medical Units Management in Hospitals. The scope of the research involved 117 respondents among which were 33 public and non-public hospitals managers from Podkarpacie Region and 84 people were the nurse administration. The author's questionnaire used in the research included 64 statements to be used in self-assessment of the management style based on Reddin 3D Leadership Model.

After the research analysis it was proven that the most commonly used style by management and nurse administration is the Executive, however, the least preferential style was the Autocratic (Strychno, Wdowiak, Kruk, 2004).

Further research on the management styles in relation to seniority in health care centres was conducted by E. Strychno, L. Wdowiak, K. Kulczycka. The subject 
matter of the study were 84 people from the nurse administration, namely, head nurses, matrons and ward nurses. The management style self-assessment questionnaire was used in the analysis. The subject matter of the assessment was the management styles proposed by Reddin and modified by the author of the thesis.

The results of the study showed that the young managers with ten years on the position as well as those exceeding 21 years on the position were classified as Executives. While the head nurses between 11 to 20 years on the manager positions were classified as Developer (Strychno, Wdowiak, Kulczycka, 2005).

The management styles research study was conducted among 247 managers by means of managerial grid by $\mathrm{H}$. Fotyn. Self-assessment managerial style questionnaire by Tokarski was used in this study (Tokarski 1996). The author qualified 200 correctly filled in questionnaires. The dominant group of the respondents was male $(60 \%)$. The managers whose questionnaires were qualified for the analysis had a university or college degrees. The results of the study are shown in Picture 5.

Picture 5. Management style of 200 managers in \%

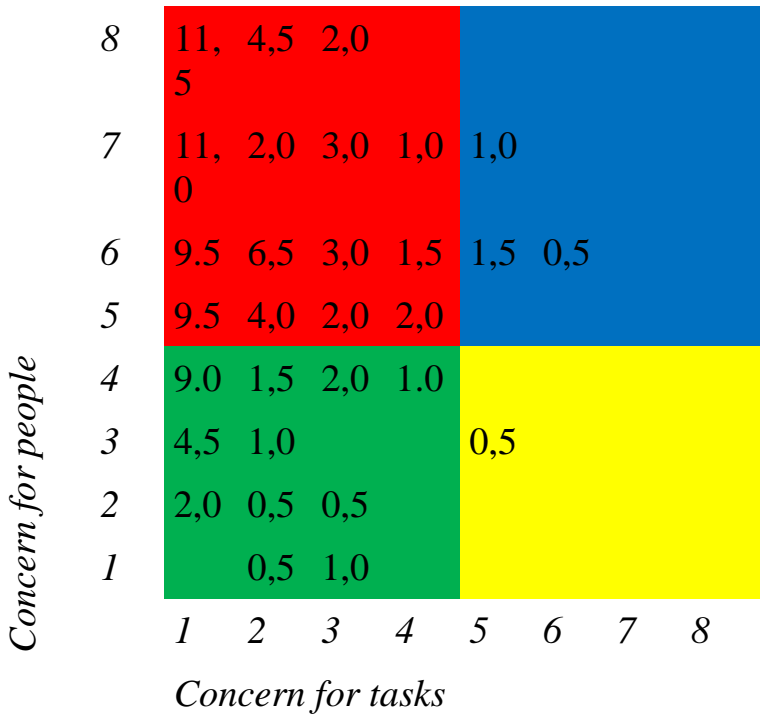

Source: H Fotyn, 2006 'Siatka kierownicza" w praktyce menadżerskiej" [Managerial grid in managerial practice] Studies and materials - The Faculty of Management Warsaw University, p. 91.

The majority of the managers use the Country Club Style (73\%). Liberal managers constitute $23.5 \%$ while integrated managers $3 \%$. In the whole group, it was only $0.5 \%$ that belonged to the autocratic managers (Fołtyn, 2006). 
Approximately 500 Polish managers participated in the research over the management style, decision-making and manager duties preferences. They had to answer 80 behavioural questions describing the preferable behaviour. Each interviewee was assessed according to his style preferences on a scale from 0 to 8 . Zero meant that it is the manager's style. The analysis has shown that the majority of the managers can be described in one or two phrases:

- a fire-fighter extinguishing fires and doing many things simultaneously,

- democratic - the supporter of collegial decision-making,

- bureaucratic - minding the law and order

- autocratic - independent decision-making and management,

- a supporter of participation and delegating powers.

The supporter of participation is a predominant style among the identified styles. A bit less popular was a fire-fighter style, and democratic style came as third. The author pays attention to the high score of the fire-fighter style, which, in fact is disadvantageous for the companies. The chaotic manager, usually badly organised and leaving the completion of the tasks till the end of stable long-term operation.

\section{Conclusion}

The thesis presents the results of management style research in various companies and institutions. The results obtained by different authors indicated that Polish managers represent democratic style regardless of the type of company. The similar situation could be noticed in case of uniformed services - police. Executive style was predominant in health care centres, which according to Reddin is a more effective style. Without regard for the fact whether it was a public sector institution or a commercial one, the managers' concerns for tasks and people are particularly important.

\section{References}

Břečková, P. , Havlíček, K., (2013). Leaders Management and Personnel Controlling in SMEs. European Research Studies, Volume XVI, Issue (4), Special Issue on SMEs.

Dąbrowski R., (2010), 'Styl kierowania pracownikami w Urzędzie Pocztowym Nr1 oraz Urzędzie pocztowym nr 2 w Ostrołęce" [Management Styles in Post Office no.1 and no. 2 in Ostroleka], (High Economic-Social School in Ostroleka, typescript).

Fotyn H, (2006), ", „Siatka kierownicza” w praktyce menadżerskiej” [Managerial Grid in practice]. Studies and materials - The Faculty of Management Warsaw University, 2, 83-97.

Gołębiewska G., (2000), 'Kierowanie zespołami kierowniczymi” [Managing the Teams of Managers], Red. nauk.: T. Białecki, J. Faryś, Podstawy organizacji i zarządzania” [The Basis of management], Wyd. 1, (Szczecin: Wydawnictwo Naukowe Uniwersytetu Szczecińskiego).http : //encyklopedia.pwn.pl/lista.php?co=autokracja, 06.05.2010r., godz. 21.51. http : //encyklopedia.pwn.pl/lista.php?co=demokracja, 06.05.2010r., godz. 22.17 . 
Havlíček, K., Thalassinos I.E. and Berezkinova, L. (2013). Innovation Management and Controlling in SMEs. European Research Studies, Volume XVI, Issue (4), Special Issue on SMEs.

Havlíček, K. and Schlossberger, O. (2013). New Trends of Management of European SMEs: The M-C Model . European Research Studies Journal, 16 (4), Special Issue on SMEs.

Kaczmarek B., Cz. Sikorski, (2011), 'Podstawy zarządzania” [The Basis of the Management], (High Economic-Social School in Ostroleka, Ostrołęka).

Kieżun W., (1998), 'Sprawne zarządzanie organizacją" [Efficient Management of the Organisation], Wyd. 2, (Warszawa: Oficyna Wydawnicza SGH)

Kobyliński W., (2005), 'Podstawy współczesnego zarządzania” [The Basis of the Modern Management], Wyd. 1, (Łódź: Społeczna Wyższa Szkoła Przedsiębiorczości i Zarządzania w Łodzi).

Kuczyńska K., (2010), ’'Style kierowania pracownikami na przykładzie sklepów Stokrotka w Ostrołęce" [Management Styles in Stokrotka Supermarkets in Ostroleka], (Wyższa Szkoła Ekonomiczno - Społeczna w Ostrołęce, typescript).

Kurnal J., (1976), '’Nowe spojrzenie na proces podejmowania decyzji kierowniczych” [New Approarch on the Decision-making Process], „Przegląd Organizacji”, nr 4-5.

Lendzioszek E., (2010), '’Style kierowania w jednostce samorządu terytorialnego na przykładzie Urzędu Miasta w Ostrołęce" [Management Styles in Local Government Units Based on Town Hall in Ostroleka], (High Economic-Social School in Ostroleka, typescript).

March J. G., Simon H. A., (1964), ’Teoria organizacji” [Organisations], Wyd. 1, (Warszawa: Polskie Wydawnictwo Ekonomiczne).

Mroziewski M., (2010), 'Styl zarządzania jako instytucjonalny czynnik kreowania kapitału przedsiębiorczości organizacyjnej” [Management Style as an Institutional Factor in Creating Capital], Wyd. 1, (Gdańsk: Wydawnictwo Uniwersytetu Gdańskiego)

Mroziewski M., (2005), ’'Style kierowania i zarządzania” [Management Styles], Wyd. 1, (Warszawa: Centrum Doradztwa i Informacji Difin sp. z o. o.)

Nawrocki D., (2010), '’Style kierowania ma przykładzie komendy Powiatowej Policji w Wyszkowie" [Management Styles in County Police Headquarters in Wyszkow], (High Economic-Social School in Ostroleka, typescript)

Osowska J., (2010), ' Style kierowania pracownikami w firmie Kross” [Management Styles in Kross Company], (High Economic-Social School in Ostroleka, typescript)

Pardo B.A., (2010), ' 'Style kierowania w przedsiębiorstwie produkcyjnym” [Management Styles in the Production Company], (High Economic-Social School in Ostroleka, typescript)

Penc J., (2000), ' Kreatywne kierowanie" [Creative Leadership], Wyd. 1, (Warszawa: Agencja Wydawnicza PLACET)

Pocztowski A., (2003), 'Zarządzanie zasobami ludzkimi” [Human Resourses Management], Wyd. 1, (Warszawa: Polskie Wydawnictwo Ekonomiczne S. A.)

Pomykało W., (1995), 'Encyklopedia biznesu" [Business Encyclopaedia], Wyd. 1, Warszawa: Fundacja INNOWACJA, Vol. 2

Stachurska K., (2010), "Style kierowania na przykładzie Banku Spółdzielczego" [Management Styles in Cooperative Bank in Goworowo], (High Economic-Social School in Ostroleka, typescript).

Strychno E., K. Kulczycka, (2003), 'Style kierowania w praktyce zarządzania zespołami położnych" [Styles of managing in practice management the midwives' teams], ANNALES UNIVERSITATIS MARIAE CURIE-SKŁODOWSKA LUBLIN POLONIA, VOL.LVIII, SUPPL. XIII, 24, SECTIO D, 204-20 
Strychno E., L. Wdowiak, K. Kulczycka, (2005), ’'Staż pracy jako wyznacznik stylu kierowania" [Training period of work as determinant of managing style], ANNALES UNIVERSITATIS MARIAE CURIE-SKŁODOWSKA LUBLIN POLONIA VOL.LX, SUPPL. XVI, 514 SECTIO D, 275-278

Strychno E., L. Wdowiak, W. Kruk, (2004), ’'Zarządzanie zespołami medycznymi w szpitalach" [Managing the Medical Teams in Hospitals], Zdrowie Publiczne; 114(3) 315-318.

Szewczyk R., (2007), '’Podziel się władzą. Najpopularniejsze role kierownicze i style zarządzania polskich szefów” [Share your Powers. The Most Popular Management Styles and Roles of Polish Managers], Personel i zarządzanie [Personnel and management], nr 8(209), 59-61.

Thalassinos, E., Ugurlu, E., \& Muratoglu, Y. (2012). Income Inequality and Inflation in the EU. European Research Studies, 15(1), 127.

Thalassinos, E. I., Ugurlu, E., \& Muratoglu, Y. (2015). Comparison of Forecasting Volatility in the Czech Republic Stock Market. Applied Economics and Finance, 2(1), 11-18.

Tokarski S., (1997), '’Kierowanie ludźmi” [Managing People], (Wydawnictwo Miscellanea, Koszalin).

Tokarski S., (1996), 'SSamoocena efektywności kierowania” [Self-assessment of the Effective Managing], (Wydawnictwo WG. Gdańsk) . 